\title{
Expression of Macrophage Procoagulant Activity in Murine Systemic Lupus Erythematosus
}

\author{
E. H. Cole, ${ }^{\star}$ J. Sweet, $¥$ and G. A. Levy\$

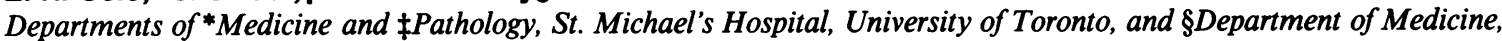 \\ Mount Sinai Hospital, University of Toronto, Toronto, Canada
}

\begin{abstract}
To explore the induction of monocyte/macrophage procoagulant activity in autoimmune disease, the BXSB murine model of systemic lupus erythematosus was studied. Splenic macrophage procoagulant activity rose coincident with age and the development of glomerulonephritis from $38 \pm 6 \mathrm{mU} / 10^{6}$ macrophages at 1 mo to a maximum of $29,000 \pm 15,000 \mathrm{mU}$ at $4 \mathrm{mo}$. Macrophages from 1-mo-old mice could be induced to express a 1,000-fold increase in monocyte/macrophage procoagulant activity when incubated with lymphocytes or lymphocyte supernatants from 5-mo-old mice. Plasma from 5-mo-old but not from 1-mo-old mice was able to induce the production of the lymphokine by cells from 1-mo-old animals. This lymphokine was not interleukin 1,2 , or gamma interferon. We conclude that induction of monocyte/macrophage procoagulant activity parallels disease development in the male BXSB mouse, is dependent on the interaction between lymphocytes and plasma factors, and may be important in mediation of injury in lupus nephritis.
\end{abstract}

\section{Introduction}

It is now well recognized that the synthesis and secretion of procoagulant activity (PCA) ${ }^{1}$ by monocyte/macrophages (Mo/ $\mathrm{Ma}$ ) is an integral component of the host's immune response $(1,2)$. These cells can be stimulated by a number of immunostimulatory molecules in collaboration with $\mathrm{T}$ lymphocytes to produce direct activators of the coagulation system (3). The induction of this Mo/Ma PCA is tightly controlled by both helper and suppressor cells as well as soluble mediators (4). Furthermore, Geczy et al. have shown that Mo/Ma production of PCA is a measure of antigen specific stimulation (5).

Studies by Schreiner et al. have suggested that proliferating cells in glomerulonephritis (GN) are derived from circulating monocytes as well as intrinsic glomerular cells (6). Holdsworth and colleagues, in experimental nephritis in the rabbit, have shown that macrophages are present during the development of

Address correspondence to Dr. Cole, St. Michael's Hospital, 30 Bond St., Room 41, B Wing, Toronto, Ontario M5B 1W8 Canada.

Received for publication 17 December 1985 and in revised form 20 June 1986.

1. Abbreviations used in this paper: BG, beta glucuronidase; BUN, blood urea nitrogen; Con A, concanavalin A; GN, glomerulonephritis; IC, immune complex; IL-1 and IL-2, interleukin 1 and 2; LPS, lipopolysaccharide; Mo/Ma, monocyte/macrophage; PA, plasminogen activator; PCA, procoagulant activity; PMSF, phenylmethylsulfonyl fluoride; TBS, Tris-buffered saline.

J. Clin. Invest.

(c) The American Society for Clinical Investigation, Inc. 0021-9738/86/10/0887/07 \$1.00

Volume 78 , October 1986, 887-893 injury, and depletion with a specific anti-macrophage serum was able to abrogate glomerular injury (7). Other studies have pointed out the importance of the coagulation system in $\mathrm{GN}$ in both experimental models and human disease $(8,9)$.

We have shown that elevation of monocyte PCA correlates with the presence of proliferative $\mathrm{GN}$ in patients with systemic lupus erythematosus (10). More recently, Wiggins and colleagues demonstrated an elevation in PCA in isolated glomeruli during the development of nephrotoxic nephritis at a time when disease and renal dysfunction were developing (11). Thus, there is good evidence that monocyte PCA is intimately involved in mediation of injury in both human and experimental GN; however, the mechanisms responsible for the induction of PCA in vivo are not well understood.

The BXSB male mouse develops a lupuslike syndrome consisting of a fatal immune complex (IC) GN, thymic atrophy, and lymphoid hyperplasia. $50 \%$ mortality occurs at 5 mo (12). Some investigators have reported increases in numbers of $\mathrm{Mo} /$ Ma with disease progression in these mice; however, no studies of macrophage function have been reported (13).

The purpose of these studies was to determine whether PCA might also play a role in murine lupus nephritis and if so to examine the mechanisms responsible for its induction.

\section{Methods}

Mice

BXSB male mice, 4 wk of age, were obtained from Jackson Laboratories, Bar Harbour, ME, and were housed in the Department of Laboratory and Animal Services at the University of Toronto, Blood urea nitrogen (BUN) was determined using Azostix (Miles Laboratories, Rexdale, Ontario, Canada).

\section{Cell isolation}

Spleen cells. Spleens were removed aseptically from BXSB mice and cells were suspended in RPMI medium (Flow Laboratories, Mississauga, Ontario, Canada) as previously described (1). Mononuclear cells were isolated by centrifugation over Ficoll-Hypaque (density 1.034) at 1,400 $g$ at $22^{\circ} \mathrm{C}$ for $12 \mathrm{~min}(1)$. The cells at the interface were removed and adjusted to $1 \times 10^{6}$ splenic mononuclear cells per milliliter.

Lymphocytes and monocytes were separated by adherence to fibronectin (derived from plasma)-coated plastic flat-bottomed 24-well plates (14) with a diameter of $16 \mathrm{~mm}$ (Linbro Plastics, Maclean, VA) in $1 \mathrm{ml}$ vol in complete medium (RPMI 1640) containing $10 \%$ fetal calf serum and $25 \mu \mathrm{g} / \mathrm{ml}$ aureomycin, grade II (Sigma Chemical Co., St. Louis, MO). After a 120-min incubation, the nonadherent cells were washed free from the plate and the adherent cells were recovered by incubation at $4^{\circ} \mathrm{C}$ for 20 min with $1 \mathrm{ml}$ of Puck's saline A, pH 7.4 (Gibco Laboratories, Mississauga, Ontario, Canada), containing $3 \mathrm{mM}$ ethylene diaminotetraacetic acid (EDTA) and 3\% bovine serum albumin (Sigma Chemical Co.). The recovery of cells was $>84 \%$ and viability was $>95 \%$ as demonstrated by trypan blue exclusion. Lymphocytes were defined by failure of adherence, morphology, and by failure of uptake of neutral 
red and were $<1 \%$ esterase positive. Monocytes were defined by morphology, uptake of neutral red, and were $>96 \%$ esterase positive (1).

Peritoneal cells. Peritoneal exudate cells were obtained by injecting mice with $2 \mathrm{ml}$ of Brewer's Thioglycollate (Difco Laboratories, Detroit, MI), $\mathrm{pH} 6.1 .4 \mathrm{~d}$ later, the peritoneal cavities were lavaged with $10 \mathrm{ml}$ RPMI 1640 containing 10 U preservative-free heparin (Connaught Laboratories, Toronto, Canada). Approximately $10-15 \times 10^{6}$ peritoneal exudate cells per mouse were obtained and cells from a minimum of three mice were pooled for most experiments. The cell suspensions contained $>96 \%$ macrophages as identified by morphology, latex ingestion, and nonspecific esterase staining ( $<3 \%$ neutrophils and $<1 \%$ lymphocytes) with a viability of $>98 \%$ as assessed by trypan blue exclusion.

\section{$P C A$}

Samples of viable cells or frozen-thawed and sonicated cells were assayed for the capacity to shorten the spontaneous recalcification time of human plasma in a one-stage clotting assay, as described previously (1). Purified splenic mononuclear cells, macrophages, or lymphocytes at $1 \times 10^{6} / \mathrm{ml}$ in $12 \times 75-\mathrm{mm}$ polypropylene tubes (Falcon Plastics, Div. Becton-Dickinson \& Co., Oxnard, CA) were subjected to three cycles of freeze-thaw and sonication (total content PCA). To $0.1 \mathrm{ml}$ of the cellular homogenate or viable cells at $37^{\circ} \mathrm{C}$ was added $0.1 \mathrm{ml}$ of citrated normal human platelet-poor plasma or factor-deficient plasma (Helena Laboratories, Beaumont, TX), and $0.1 \mathrm{ml}$ of $25 \mathrm{mM} \mathrm{CaCl}_{2}$ was added to start the reaction. The time in seconds for the appearance of a fibrin gel was recorded. To establish units, a rabbit brain thromboplastin standard at $36 \mathrm{mg}$ dry mass per milliliter (Dade Div., American Hospital Supply, Miami, FL) was assigned a value of $100,000 \mathrm{mU}$. Log dilutions of this standard were used to derive a standard curve as previously described (1). Similarly, log dilutions of Mo/Ma expressing PCA gave a linear curve parallel to the thromboplastin standard when plotted on a log-log scale. Media with or without $10 \%$ fetal calf serum and buffers were all without activity.

\section{Endotoxin contamination}

All media, buffers, supernatants, and plasmas (delipidated with chloroform) (15) were assayed for endotoxin contamination by a standard limulus assay (E. Toxate; Sigma Chemical Co.) and contained $<0.1 \mathrm{ng} / \mathrm{ml}$ of endotoxin, the lower limits of the assay.

\section{Renal pathology}

Whole kidneys were removed from all animals and specimens for histologic study were embedded in paraffin. Sections were stained with hematoxylin and eosin and were reviewed by a pathologist (Dr. Sweet) in a double-blind fashion. Pathologic diagnosis was made according to World Health Organization criteria (16).

\section{Interleukin 1 (IL-1) production}

Supernatants capable of inducing PCA were assessed for the presence of IL-1 activity by the technique described by Mizel et al. (17). The sternum of young ( $<4 \mathrm{wk}$ of age) BALB/cJ mice was split and the thymus was dissected free from the mediastinum and placed in a petri dish containing RPMI 1640. All cells were extracted from the thymus by gentle teasing with forceps. The thymocytes were cultured $\left(1.0 \times 10^{6} /\right.$ well) for $72 \mathrm{~h}$ in 96 flat-bottomed microtest plates in $0.2 \mathrm{ml}$ of complete medium, and in dilutions of the supernatants capable of stimulating PCA production, in the presence or absence of concanavalin A (Con A) $(5 \mu \mathrm{g} / \mathrm{ml})$ (Sigma Chemical Co.). After $48 \mathrm{~h}, 1 \mu \mathrm{Ci}$ of $\left[{ }^{3} \mathrm{H}\right]$ methylthymidine $(2 \mathrm{Ci} / \mathrm{mM})$ (Amersham Canada Ltd., Mississauga, Ontario, Canada) was added. The cells were incubated for an additional $24 \mathrm{~h}$ and harvested onto fiberglass filters with a MASH II (Multiple Automated Sample Harvester, Microbiological Assoc.). For each supernatant, results were expressed by subtracting the counts per minute of thymocytes cultured with supernatant in the absence of Con A from the counts per minute of thymocytes cultured with Con A. An IL-1-positive supernatant obtained by culturing BALB/cJ monocytes in the presence of lipopolysaccharide for 24-48 h was used as a positive control and generated $>38,000 \mathrm{cpm}$ in young thymocytes from BALB/cJ mice.

\section{IL-2 production}

IL-2 activity was assayed as described by Gillis et al. (18). CTLL IL-2dependent cells, provided by Dr. Gordon Mills (Hospital for Sick Children, Toronto, Canada), were grown in IL-2-containing supernatants, washed, and adjusted to $2 \times 10^{5} / \mathrm{ml}$ of complete medium, and $0.1 \mathrm{ml}$ of the cell suspension was distributed into each well of flat-bottom microtiter plates. Each well also received $0.1 \mathrm{ml}$ of a $\log _{2}$ serial dilution of the supernatant to be titrated and cultures were incubated for $48 \mathrm{~h}$. Tritiated thymidine $(1 \mu \mathrm{Ci})$ was added, and $8 \mathrm{~h}$ later the cultures were harvested and $\left[{ }^{3} \mathrm{H}\right]$ thymidine incorporation measured. Each sample was tested in triplicate. $1 \mathrm{U}$ of IL-2 activity was defined as the amount of IL2 -containing supernatant that produced $50 \%$ of the maximal proliferative response obtained with the reference IL-2 sample. A reference IL-2 sample was obtained by stimulating normal rat spleen cells with $C$ on $A$ and was used as a positive control as well as for routine maintenance of the CTLL cells.

\section{Plasminogen activator (PA)}

Plasminogen was isolated from citrated normal human fresh frozen plasma according to a modification of the method of Deutsch and Mertz (19). $70 \mathrm{IU}$ ancrod (Connaught Laboratories) was added to each liter of plasma and the plasma was stirred gently overnight at $4^{\circ} \mathrm{C}$. After filtration, the plasma was diluted $1: 1$ with $0.1 \mathrm{M}$ phosphate buffer, $\mathrm{pH} 7.4$, containing $3 \mathrm{mM}$ EDTA and $2 \mathrm{mM}$ phenylmethylsulfonyl fluoride (PMSF) and was loaded onto a $2.0 \times 30-\mathrm{cm}$ Sepharose-lysine column (Pharmacia Chemicals, Montreal, Quebec, Canada). The column was washed with $0.1 \mathrm{M}$ phosphate buffer, $\mathrm{pH} 7.4$, at $22^{\circ} \mathrm{C}$ until the absorbance at 280 $\mathrm{nM}$ was $<0.01$ and the plasminogen was eluted from the column with $0.2 \mathrm{M}$ epsilon amino caproic acid in $0.3 \mathrm{M}$ phsophate, $\mathrm{pH} 7.4$, containing $3 \mathrm{mM}$ EDTA and $2 \mathrm{mM}$ PMSF at $4^{\circ} \mathrm{C}$. The plasminogen was dialyzed

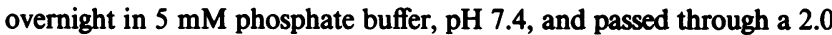
$\times 30$-cm Sephadex G25 medium column at $4^{\circ} \mathrm{C}$ (Pharmacia Chemicals). The protein peak was recovered and dialyzed against $0.1 \mathrm{M}$ Tris-buffered saline (TBS), $\mathrm{pH} 6.4$, at $4^{\circ} \mathrm{C}$. Protein concentration was determined in a standard Lowry assay and plasminogen was stored in aliquots at $-70^{\circ} \mathrm{C}$. Purity of plasminogen was determined by polyacrylamide gel electrophoresis in which a 90,000-mol-wt doublet was seen when the gel was loaded with $40 \mu \mathrm{g}$ protein.

Purified fibrinogen (Kabi; Kabivitrum, Stockholm, Sweden) was radioiodinated enzymatically with immobilized lactoperoxidase (Biorad Radiochemicals Inc., Mississauga, Ontario, Canada) according to the method of York and Blomback (20). Radiolabeled fibrinogen was diluted with cold fibrinogen in $0.1 \mathrm{M} \mathrm{TBS}$, pH 7.4, to give $20 \mu \mathrm{g}$ of protein per $250 \mu$ containing $300,000 \mathrm{cpm}$. Plastic flat-bottom $16-\mathrm{mm}$ diam 24 well plates (Linbro Plastics) were then coated with $250 \mu$ l of this ${ }^{125} \mathrm{I}$ fibrinogen and dried at $22^{\circ} \mathrm{C}$ for $3 \mathrm{~d}$. Then fibrinogen was converted to fibrin by adding $1 \mathrm{ml}$ of $10 \%$ acid-treated fetal calf serum depleted of plasminogen by passage over a Sepharose-lysine column (19) in $0.1 \mathrm{M}$ TBS, pH 7.4, as a source of thrombin to each well for $4 \mathrm{~h}$ at $37^{\circ} \mathrm{C}$ in a $5 \% \mathrm{CO}_{2}$ environment. In each well, $1 \mathrm{ml}$ of $0.1 \%$ gelatin in $0.1 \mathrm{M}$ TBS, pH 7.4, and $10 \mu \mathrm{g}$ of plasminogen were added to $1 \mathrm{ml}$ of streptokinase (Sigma Chemical Co.), the supernatant to be tested, or $0.25 \mathrm{U}$ human plasmin (Sigma Chemical Co.), as positive controls. After a 45-min incubation at $37^{\circ} \mathrm{C}$, the supernatants were removed and counted in a gamma counter. Results are expressed as the mean percent of triplicate samples of the maximum ${ }^{125} \mathrm{I}$ released by the plasmin control according to the formula:

\% fibrinolysis $=\frac{\operatorname{cpm}(\text { supernatant })-\operatorname{cpm}(\text { background })}{\operatorname{cpm}(\text { plasmin control })-\operatorname{cpm}(\text { background })} \times 100$,

$\operatorname{cpm}($ plasmin control $)=$ maximum cpm released by a plasmin standard,

and $\operatorname{cpm}$ (background) $=$ cpm released by media .

Plasminogen, RPMI 1640, and streptokinase (each alone in 0.1 M TBS) did not cleave fibrin above normal background controls to which only $0.1 \mathrm{M}$ TBS had been added. 


\section{Assay for interferon}

Supernatants were assayed for the presence of gamma interferon by their ability to reduce infection of mouse hepatitis virus strain 3 in a standard plaque reduction assay as described previously (21). 100 PFU of virus were incubated with the supernatants or a National Institutes of Health (NIH) standard for gamma interferon (kindly provided by Dr. Bryan Williams, Research Institute, Hospital for Sick Children) for $30 \mathrm{~min}$ at $22^{\circ} \mathrm{C}$ and then layered onto monolayers of $\mathrm{L} 2$ cells. $1 \%$ agarose in Dulbecco's modified Eagle's medium fortified with 2\% fetal calf serum, 3( $N$-morpholino)-propane sulfonic acid (MOPS), Hepes, $N$-tri (hydroxy methyl)-3-methyl-2-aminoethane sulfonic acid (TES), and $25 \mu \mathrm{g} / \mathrm{ml} \mathrm{au}-$ reomycin (Sigma Chemical Co.) was overlayed and plates were placed in a 5\% $\mathrm{CO}_{2}$ environment for $48 \mathrm{~h}$. The cells were stained with $1 \%$ crystal violet and plaques enumerated. Units were defined by comparison to the NIH standard interferon.

\section{Beta glucuronidase (BG)}

BG was determined according to the method of Fishman based upon the hydrolysis of phenolphthalein glucuronide (22). $0.1 \mathrm{ml}$ of a homogenate of $10^{6}$ splenic macrophages was added to $0.8 \mathrm{ml}$ of $0.1 \mathrm{M}$ acetate buffer, $\mathrm{pH} 4.5$, and $0.1 \mathrm{ml}$ of $0.01 \mathrm{M}$ phenolphthalein glucuronide, $\mathrm{pH}$ 5.0 , was added to start the reaction. This was allowed to proceed for 1 $\mathrm{h}$ at $56^{\circ} \mathrm{C}$. Subsequently, $5 \mathrm{ml}$ of $0.1 \mathrm{M}$ 2-amino-2-methyl-1-propanol (amp) buffer, pH 11, was added and the absorbance read at $550 \mathrm{~nm}$. The concentration (milligrams per milliliter) was determined by comparison with phenolphthalein standards.

\section{Results}

\section{$P C A$ in $B X S B$ male mice}

The BXSB mice used in this study showed a disease pattern similar to that previously reported with $50 \%$ mortality occurring at 5 mo. In Table I, the pathologic changes occurring in the kidneys of those mice are described. This was associated with a rise in BUN from $10 \mathrm{mg} / \mathrm{dl}$ at $1 \mathrm{mo}$ to $40-60 \mathrm{mg} / \mathrm{dl}$ at $6 \mathrm{mo}$ of age (Table II).

Changes in PCA expressed by viable splenic macrophages from aging BXSB mice were striking. 1-mo-old mice had values of $37 \pm 8 \mathrm{mU} / 10^{6}$ splenic macrophages, but even by the 3rd mo of age there was a significant rise to $800 \pm 200 \mathrm{mU} / 10^{6}$ splenic macrophages, with a further elevation at 4 mo to reach a maximum of $29,000 \pm 15,000 / 10^{6}$ splenic macrophges, which was maintained through 6 mo of age (Table II). In contrast, no rise in PCA was observed before 8 mo with either BALB/c or C57Bl/ $6 \mathrm{~J}$ mice (data not shown). There was no associated rise of PA over this same time; however, there was a minimal rise in BG that was not evident until late in the course of the animals' disease, and was not consistent as shown by the large standard deviation (Table II). In separate experiments, in 1-mo-old mice,

Table I. Evolution of Renal Pathology in the BXSB Mouse

\begin{tabular}{ll}
\hline Age of mice & Renal pathology \\
\hline mo & $*$ \\
1 & $*$ \\
2 & $+\ddagger$ \\
3 & $+++\ddagger$ \\
5 & $++\ddagger$
\end{tabular}

* Denotes normal kidney.

$\ddagger+$ to +++ denotes increasing severity of proliferative GN.
Table II. Macrophage Protease Activity in the BXSB Mouse

\begin{tabular}{|c|c|c|c|c|c|}
\hline \multicolumn{2}{|l|}{ Mice } & \multirow[b]{2}{*}{ BUN } & \multirow[b]{2}{*}{$\mathrm{PCA}^{*}$} & \multirow[b]{2}{*}{ PAł } & \multirow[b]{2}{*}{ BG§ } \\
\hline Age & $\begin{array}{l}\text { Number } \\
\text { studied }\end{array}$ & & & & \\
\hline mo & & $m g / d l$ & $\begin{array}{l}m U / 10^{6} \\
\text { macrophages" }\end{array}$ & $\begin{array}{l}\text { \% maximum } \\
\mathrm{cpm}\end{array}$ & $\mu g / m l$ \\
\hline 1 & 5 & 10 & $37 \pm 8$ & $<1$ & $0.21 \pm 0.1$ \\
\hline 1.5 & 10 & 10 & $36 \pm 4$ & ๆ & I \\
\hline 2 & 8 & 10 & $55 \pm 15$ & $1.1 \pm 1$ & ๆ \\
\hline 3 & 8 & $10-20$ & $800 \pm 200$ & $1.8 \pm 1.5$ & $0.16 \pm 0.06$ \\
\hline 3.5 & 3 & $20-40$ & $1,000 \pm 200$ & $\pi$ & $\pi$ \\
\hline 4 & 4 & $20-40$ & $29,000 \pm 15,000$ & ๆ & $0.13 \pm 0.015$ \\
\hline 5 & 8 & $40-60$ & $26,500 \pm 4,000$ & I & $\pi$ \\
\hline 5.5 & 6 & $20-40$ & $27,000 \pm 2,000$ & $<1$ & $0.63 \pm 0.35$ \\
\hline 6 & 5 & $40-60$ & $27,000 \pm 3,000$ & I & I \\
\hline
\end{tabular}

* Values are the mean \pm 1 SD.

$¥$ PA was determined in an ${ }^{125}$ I-fibrin release assay and values represent percent release as compared with a plasmin control.

$\S$ BG was determined in cellular homogenates from $10^{6}$ macrophages.

"Splenic macrophages used in these experiments.

I Not done.

PCA in splenic mononuclear cells was $5 \pm 1 / 10^{6}$ cells, in lymphocytes $3 \pm 1 / 10^{6}$ cells, and in macrophages $50 \pm 10 \mathrm{mU} / 10^{6}$ cells. In 4-mo-old animals, the value for splenic mononuclear cells was $2,800 \pm 200$, in lymphocytes $150 \pm 50$, and in macrophages $31,000 \pm 1,250 \mathrm{mU} / 10^{6}$ cells, which shows that the macrophage was the cellular source of the PCA-augmented response. Expression of PCA by viable cells was compared with total content PCA assayed in disrupted cells. In 1-mo-old mice, the value obtained from viable splenic cells was $45 \pm 10$, whereas total content was $35 \pm 5 \mathrm{mU} / 10^{6}$ splenic macrophages. At $5 \mathrm{mo}$, viable splenic macrophage PCA was $27,000 \pm 3,000 \mathrm{mU} / 10^{6}$ splenic macrophages, and total content was $25,500 \pm 1,500 \mathrm{mU} / 10^{6}$ macrophages, suggesting that the majority of the PCA was localized to the cell surface.

Congenitally factor-deficient human plasmas were used to characterize the PCA, and values were similar when plasma deficient in Factor VII, VIII, X, or V (Helena Laboratories) was used in the assay. However, when Factor II-deficient plasma was used, the clotting time was markedly prolonged. This was corrected by the addition of Factor II, which was devoid of contaminants as determined by sodium dodecyl sulfate (SDS) polyacrylamide gel electrophoresis (kindly provided by Dr. D. Fair, Scripps Clinic and Research Foundation, La Jolla, CA). In addition, Mo/Ma homogenates, positive for PCA, were able to induce clotting of a system containing only fibrinogen, prothrombin, and calcium. This data demonstrates that the PCA was dependent upon only Factor II, calcium, and fibrinogen for its full activity (Table III).

\section{Lymphocyte requirement for PCA induction}

Spleens from 1- and 5-mo-old mice were removed and cells harvested. Lymphocytes were separated from macrophages by cytoadherence, and macrophages were incubated alone or in combination with lymphocytes (at a ratio of 8.5:1 lymphocytes/ macrophage) for $12 \mathrm{~h}$ in complete medium in a $5 \% \mathrm{CO}_{2}$ atmosphere at $37^{\circ} \mathrm{C}$. The cells were harvested, washed three times 
Table III. Characterization of the PCA

\begin{tabular}{|c|c|c|c|c|c|c|}
\hline & \multirow{2}{*}{$\begin{array}{l}\text { Normal } \\
\text { plasma }\end{array}$} & \multicolumn{4}{|c|}{ Plasmas deficient in factor: } & \multirow{2}{*}{$\begin{array}{l}\text { Factor II-deficient } \\
\text { plasma and } \\
\text { Factor II }\end{array}$} \\
\hline & & VII & $\mathbf{x}$ & $\mathbf{v}$ & II & \\
\hline $\begin{array}{l}\text { Clotting } \\
\text { time }(s)\end{array}$ & 30 & 23 & 31 & 28 & $>120$ & 29 \\
\hline $\mathrm{PCA}(m U)$ & 2,800 & 4,600 & 2,800 & 3,200 & $<1$ & 3,100 \\
\hline
\end{tabular}

PCA represents spontaneous total content PCA per $10^{5}$ splenic macrophages from 5-mo-old BXSB mice.

in RPMI 1640, after which PCA was determined. When splenic lymphocytes and macrophages from 1-mo-old mice were mixed and incubated for $12 \mathrm{~h}$, no augmentation in PCA was found above macrophages from 1-mo-old mice alone (basal activity). In contrast, splenic macrophages alone from 5-mo-old mice or macrophages from 5-mo-old mice mixed with lymphocytes from 1-mo-old mice expressed PCA $\sim 1,000$-fold higher than levels from 1-mo-old mouse splenic macrophages (Table IV). Thus, lymphocytes from young animals were not capable of inhibiting the increased PCA found in macrophages from 5-mo-old mice. When lymphocytes from 5-mo-old mice were mixed with macrophages from one-mo-old mice and incubated for $12-18 \mathrm{~h}$, a marked rise in PCA was observed. The level of activity was similar to that found in macrophages that were isolated from 5-moold BXSB mice. Thus, lymphocytes from 5-mo-old BXSB mice were able to induce PCA expression in macrophages from young mice (Table IV).

\section{Ability of plasma to induce macrophage PCA}

In an effort to determine whether a factor(s) present in mouse plasma could stimulate PCA induction, plasma from 1- and 5mo-old mice was studied for its ability to activate peritoneal macrophages from 1-mo-old mice either alone or in the presence of lymphocytes. These data are presented in Table V.

Table IV. Lymphocyte Induction of Macrophage PCA in BXSB Mice

\begin{tabular}{|c|c|c|}
\hline \multicolumn{2}{|l|}{ Source of: } & \multirow[b]{2}{*}{ PCA } \\
\hline Lymphocyte* & Macrophageł & \\
\hline & & $\begin{array}{l}\text { mU/10 } 0^{6} \text { splenic } \\
\text { macrophages }\end{array}$ \\
\hline 1 & - & $20 \pm 10$ \\
\hline 1 & 1 & $25 \pm 10$ \\
\hline 1 & 5 & $27,500 \pm 2,500$ \\
\hline - & 5 & $25,500 \pm 1,850$ \\
\hline 5 & - & $20 \pm 10$ \\
\hline 5 & 5 & $28,500 \pm 2,000$ \\
\hline 5 & 1 & $29,500 \pm 3,500$ \\
\hline
\end{tabular}

\footnotetext{
* Lymphocytes were defined by morphology and lack of uptake of neutral red, and were $<1 \%$ esterase-positive. Numbers represent the age of mice in months from which lymphocytes were harvested. Lymphocytes were added to macrophages at a ratio of 8:5:1. $\ddagger$ Macrophages were defined by uptake of neutral red and morphology, and were $>98 \%$ esterase-positive. Numbers represent the age of mice in months from which the macrophages were harvested. $\S$ Values are mean $\pm 1 \mathrm{SD}$.
}

Table V. Induction of PCA in Peritoneal Macrophages from BXSB Mice by Plasma from 5-mo-old BXSB Mice

\begin{tabular}{|c|c|c|c|}
\hline \multicolumn{2}{|l|}{ Plasma } & \multirow{2}{*}{$\begin{array}{l}\text { Lymphocyte/ } \\
\text { monocyteł ratio }\end{array}$} & \multirow[b]{2}{*}{ PCA§ } \\
\hline Age of mouse* & Volume & & \\
\hline & $\mu l$ & & $\mathrm{mU} / 10^{6}$ macrophages \\
\hline$\#$ & $\#$ & I & $14 \pm 4$ \\
\hline 1 & 100 & 8.5 & $15 \pm 5$ \\
\hline 5 & 100 & I & $20 \pm 5$ \\
\hline 5 & 100 & 8.5 & $2,800 \pm 100$ \\
\hline 5 & 50 & 8.5 & $1,800 \pm 250$ \\
\hline 5 & 10 & 8.5 & $520 \pm 100$ \\
\hline $5,1^{11}$ & 50,50 & 8.5 & $3,100 \pm 300$ \\
\hline
\end{tabular}

* Age indicates the age of mouse in months from which plasma was collected. \# Denotes that no plasma was added.

¥ Lymphocytes and macrophages from 1-mo-old mice were mixed and plasma added for 8-12 $\mathrm{h}$ and macrophage PCA determined. $\S$ Values are the mean \pm 1 SD.

"Equal volumes of plasma ( $50 \mu \mathrm{l})$ from 1- and 5-mo-old BXSB mice were added to cells and macrophage PCA determined.

II Indicates that macrophages were then stimulated with plasma in the absence of any lymphocytes.

Peritoneal macrophages ( $>98 \%$ esterase positive) from young mice, when stimulated (while free of lymphocytes) with plasma from 1- and 5-mo-old mice, failed to produce an augmented PCA response. A marked dose-dependent rise in PCA was seen in peritoneal macrophages mixed with lymphocytes (both from 1-mo-old mice) at a ratio of 8.5:1 when mixed with plasma isolated from 5-mo-old mice, but not when mixed with plasma from 1-mo-old mice. To exclude the presence of an inhibitor of PCA induction in plasma from 1-mo-old mice, plasma from young and old mice was mixed and added to cell preparations. No diminution in PCA was seen as compared with the effect of old plasma alone, suggesting there was not an inhibitor in plasma from young mice (Table V).

To determine the lymphocyte requirement for PCA induction in response to stimulation with plasma from 5-mo-old mice, lymphocytes from the spleens of young mice were added in increasing numbers to $1 \times 10^{6} \mathrm{PEC}$, and then $50 \mu$ l of plasma from 5-mo-old BXSB mice was added. A maximum PCA response was obtained at a lymphocyte macrophage ratio of $1: 1$, and there was no further increase in PCA as the lymphocyte/ macrophage ratio was increased to 8:1 (Fig. 1).

\section{Nature of lymphocyte stimulation}

To determine whether lymphocyte stimulation occurred through the production of a soluble factor (lymphokine) or by direct cellular contact, $1 \times 10^{6}$ splenic mononuclear cells, splenic macrophages, and splenic lymphocytes, from 1-mo-old mice were stimulated with plasma from 5-mo-old mice for $18 \mathrm{~h}$. Supernatants were then collected and added to $1 \times 10^{6}$ macrophages from 1-mo-old mice that were then incubated for an additional $18 \mathrm{~h}$. The results of these studies indicated that lymphocyte supernatants from splenic mononuclear cells and lymphocytes, but not macrophages alone, were able to induce macrophage PCA in a dose-dependent fashion (Table VI). No such lymphokine was detected in supernatants from lymphocytes that had been incubated with plasma from 1-mo-old mice. In addition, 
Table VI. Induction of PCA by Lymphocyte Supernatants

\begin{tabular}{lcc}
\hline Supernatant* & Volume & PCA $\ddagger$ \\
\hline & $\mu l$ & $m U / 10^{6}$ peritoneal macrophages \\
5 & 100 & $2,200 \pm 400$ \\
5 & 50 & $487 \pm 40$ \\
5 & 10 & $183 \pm 40$ \\
5 & 0 & $47 \pm 25$ \\
1 & 100 & $67 \pm 17$
\end{tabular}

* Splenic mononuclear cells $\left(1 \times 10^{6} / \mathrm{ml}\right)$ were incubated with plasma from old $(5 \mathrm{mo})$ or young $(1 \mathrm{mo})$ BXSB mice for $18 \mathrm{~h}$ and supernatants were collected. 1 refers to the supernatant derived by incubation of $5 \times 10^{6}$ splenic mononuclear cells from 1-mo-old BXSB mice with $50 \mu$ of plasma from 1-mo-old BXSB mice. 5 refers to the supernatant derived by incubation of $5 \times 10^{6}$ splenic mononuclear cells from 1-mo-old BXSB mice with $50 \mu 1$ of plasma from 5-mo-old BXSB mice.

$\ddagger 1 \times 10^{6}$ peritoneal macrophages were incubated with supernatant for 12-18 h, washed, and assayed for total content PCA. Values are the mean $\pm 1 \mathrm{SD}$.

supernatants obtained from lymphocytes from 5-mo-old mice, when placed in culture alone for $18 \mathrm{~h}$, were able to induce an augmented PCA response in young peritoneal/splenic macrophages (data not shown). This PCA-inducing factor, isolated from supernatants derived from incubating plasma from 5-moold mice with lymphocytes from 1-mo-old mice, as well as that derived from lymphocytes from 5-mo-old mice incubated alone, was not IL-1, IL-2, or gamma interferon, as determined by assays carried out as outlined in Methods (data not shown).

\section{Discussion}

The BXSB is a recombinant inbred mouse strain derived from a cross between a C57BL/6 female and a SB/LE male. Almost $100 \%$ of these mice develop a progressive lethal lupuslike disease that affects males much earlier than females (23). Like other autoimmune mouse strains, these animals develop lymphoid hyperplasia, B cell hyperactivity, autoantibodies, circulating immune complexes (IC), complement consumption, thymic atrophy, and IC GN. The male mice have a $50 \%$ mortality at 5 mo and a $90 \%$ mortality at $8 \mathrm{mo}$, with acute exudative and proliferative $\mathrm{GN}$ being the major cause of death (24).

The pathogenesis of murine lupus is not well understood, but the production of autoantibodies is an associated phenomenon in all strains. Shoenfeld and Schwartz have pointed out that two mechanisms are able to initiate the production of autoantibodies: impaired immunoregulation, which causes the development of autoantibodies against a family of autoantigens, and the idiotype cascade, which could contribute to the production of autoantibodies by means of loopholes in the rules against autoimmunization (25). Mo/Ma play a major role in the immune and inflammatory response to a variety of agents. These responses can occur consequent to the interactions of these cells with $\mathrm{T}$ and $\mathrm{B}$ lymphocytes and their products, or through direct interaction of the agents with the Mo/Ma (26). Activation of the coagulation system is an important aspect of the response to infection in host defense, and is a necessary component of the delayed cutaneous hypersensitivity reaction (27).
Mo/Ma can be stimulated by lipopolysaccharide (LPS), antigens, immune complexes, viruses, and lipoproteins to augment their expression of PCA (28). The cellular pathways through which this response occurs are not entirely clear and may depend on the particular stimulating agent. Recent evidence suggests a direct role for lymphocytes in the expression of PCA that is induced by LPS and IC $(29,30)$. However, others have suggested that LPS can induce Mo/Ma PCA directly $(30,31)$. Geczy and colleagues have shown that an Lyt $1+T$ cell produces a lymphokine that elicits expression of PCA by adherent cells in response to antigen stimulation (32), and present further evidence to suggest that this lymphokine is not IL-1, IL-2, or gamma interferon (33). Edgington et al. have described three different T lymphocyte-dependant major pathways for induction of PCA; the first or rapid pathway appears operative in LPS and IC induction of PCA, the second in allogeneic induction, and the third in antigen-specific induction of PCA (26).

A number of studies have shown the relevance of $\mathrm{Mo} / \mathrm{Ma}$ and of the coagulation system in GN $(6-9,34)$. Accordingly, we wondered whether this could indicate a role for Mo/Ma PCA in GN. Previous studies showed that a profound increase in the expression of PCA, which was found to be a direct prothrombinase, correlated with endocapillary proliferation in patients with lupus nephritis and suggested that PCA might be a mediator of tissue injury in this disease (10). The importance of these observations has been strengthened by the more recent observations of Wiggins et al. using isolated glomeruli, which show an increase in Mo/Ma PCA that is associated with the development of disease and injury in nephrotoxic nephritis in the rabbit (11).

The studies presented here demonstrate that the expression of PCA in splenic and peritoneal $\mathrm{Mo} / \mathrm{Ma}$ correlates with the development of GN in the BXSB mouse and elucidate a mechanism for the induction of this monokine. A 1,000-fold increase in PCA was associated with the development of disease, and as we have reported in humans with lupus nephritis (10), this procoagulant was a prothrombinase. This increase in expression of PCA does not appear to reflect a global activation of the Mo/ $\mathrm{Ma}$, as evidenced by the failure of PA and BG to increase in a similar manner. The observation that most of the PCA was localized to the cell surface suggests either that the nature of the stimulant is different from others described, or, that prolonged in vivo stimulation, as opposed to short-term in vitro exposure, minimizes intracellular storage and encourages transport of PCA to the cell surface.

The induction of PCA is lymphocyte dependent, as is evidenced by the observation that lymphocytes from older mice are able to induce increases in PCA in macrophages from young mice similar to levels comparable with the spontaneous PCA seen in cells from animals with severe disease. The lymphocyte effect on the Mo/Ma occurred via soluble mediator(s), and this lymphokine was not IL-1, IL-2, or gamma interferon, molecules that are known to be relevant in other systems. A molecule(s) in the plasma of older mice seems to be responsible for inducing the lymphokine. These data agree with those of Geczy (33) and Edgington (26) who have suggested that a lymphokine specific to the PCA system is relevant in antigen-induced and allogeneicinduced PCA (macrophage procoagulant-inducing factor [MPIF]). MPIF behaves like a classical lymphokine in that it requires an accessory cell (macrophage) for its expression, although the exact cellular requirement for MPIF induction in our system is unclear at the present time. The increase in in- 


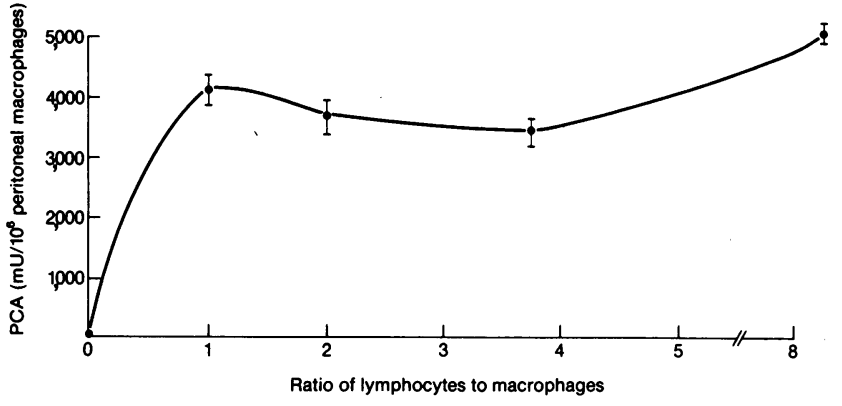

Figure 1. Lymphocyte requirement for induction of PCA in peritoneal macrophages from BXSB mice. Peritoneal macrophages $\left(1 \times 10^{6}\right)$ were incubated with increasing numbers of lymphocytes for $18 \mathrm{~h}$ with $50 \mu \mathrm{l}$ of plasma from 5-mo-old BXSB mice. The cells were washed and assayed for total content PCA (-•-). Results represent the mean \pm 1 SD of four sets of independent experiments.

duction of PCA is related to the interaction of lymphocytes with factor(s) in the plasma, since plasma from older but not younger mice was able to initiate the sequence of events described above in vitro. Of note, all 5-mo-old mouse plasmas were not equipotent in increasing PCA expression although all were definitely positive. This suggests that the quantity of the circulating stimulating factor(s) varies from mouse to mouse and could account for variable disease activity. Thus, data in Fig. 1 and Table V differ in some quantitative aspects. The relevant molecule(s) in the plasma is not known, but a potential candidate would be IC, since these are known to be present in the plasma from the BXSB mouse as well as other autoimmune mice, and since it is known that IC are able to increase Mo/Ma PCA in vitro, $(12,35)$.

The studies of Geczy et al. demonstrate antigen-specific induction of PCA in experimental allergic encephalitis (36). They have shown that mononuclear cells derived from animals immunized with antigens expressed no spontaneous PCA; however, when these cells were rechallenged in vitro by the same antigen, a large increment in PCA was observed. The expression of PCA was seen only in those animals that developed disease. These observations are further evidence in favor of a role for PCA in the mediation of injury in autoimmune disease.

The results of our studies in the BXSB model underline the importance of PCA expression in the development of certain lesions found in spontaneous autoimmune disease in mice. The link between PCA induction and the immunoregulatory abnormalities felt to be relevant in murine lupus is uncertain. We were unable to demonstrate a soluble or lymphocyte-associated suppressor factor capable of blocking PCA induction in young mice. Therefore, any disturbance in immunoregulation must result in the production of a stimulating plasma factor(s). In view of our current understanding of the pathogenesis of $\mathrm{GN}$, and the data presented in this paper, one could postulate that impaired immunoregulation results in the development of IC in the plasma with age in BXSB mice. These IC might then trigger the induction of a PCA-inducing lymphokine with a major increase in the expression of Mo/Ma PCA. This appears to be intimately associated with the development of $\mathrm{GN}$, although the exact mechanisms remain to be elucidated.

PCA could be relevant simply as a direct activator of the coagulation system, with resultant regional microcirculatory disturbances in conjunction with fibrin deposition. However, since thrombin is a potent chemoattractant for monocytes, monocyte production of prothrombinase might promote the development of cellular infiltration in GN (37). Finally, PCA might alter receptors on the target cell surface, making these cells more susceptible to attack by other cellular systems. Further experiments will provide further insight into the exact role of PCA in autoimmune GN.

\section{Acknowledgments}

The authors gratefully acknowledge the technical assistance of L. S. Fung and J. Schulman, and Ms. Vilma Soffer for typing of the manuscript.

Dr. Levy is the recipient of a Medical Research Council of Canada Scholarship. This work was supported by a grant from the Kidney Foundation of Canada, and by Medical Research Council of Canada grants MA 6787 and MA 8887.

\section{References}

1. Levy, G. A., and T. S. Edgington. 1980. Lymphocyte cooperation is required for amplification of macrophage procoagulant activity. J. Exp. Med. 151:1232-1234.

2. Edwards, R. L., and F. R. Rickles. 1980. The role of monocyte tissue factor in the immune response. Lymphokine Res. 1:181-210.

3. Schwartz, B. S., G. A. Levy, D. S. Fair, and T. S. Edgington. 1982. Murine lymphoid procoagulant activity induced by bacterial lipopolysaccharide and immune complexes is a monocyte prothrombinase. J. Exp. Med. 155:1464-1479.

4. Levy, G. A., B. S. Schwartz, L. K. Curtiss, and T. S. Edgington. 1985. Regulatory roles of $\mathrm{Tu}$ and Ty cells in the collaborative cellular initiation of the extrinsic coagulation pathway by bacterial lipopolysaccharide. J. Clin. Invest. 76:548-555.

5. Geczy, C. L., E. Farram, D. Moon, P. Meyer, and I. McKenzie. 1983. Macrophage procoagulant activity as a measure of cell mediated immunity in the mouse. J. Immunol. 130:2743-2749.

6. Schreiner, G. F., R. S. Cotran, V. Pardo, and E. R. Unanue. 1978. A mononuclear cell component in experimental immunological glomerulonephritis. J. Exp. Med. 147:369-378.

7. Holdsworth, S. R., T. J. Neal, and C. B. Wilson. 1981. Abrogation of macrophage dependant injury in experimental glomerulonephritis in the rabbit. use of an antimacrophage serum. J. Clin. Invest. 8:686-698.

8. Holdsworth, S. R., M. M. Thomson, and R. C. Atkins. 1979. The effect of defibrination on macrophage participation in rabbit nephrotoxic nephritis: studies using glomerular culture and electron microscopy. Clin. Exp. Immunol. 37:38-43.

9. Pollak, V. E., H. I. Glueck, M. A. Weiss, A. Lebron-Berges, and M. A. Miller. 1982. Defibrination with ancrod in glomerulonephritis: effects on clinical and histologic findings and on blood coagulation. Am. J. Nephrol. 2:195-207.

10. Cole, E. H., J. Schulman, M. Urowitz, E. Keystone, C. Williams, and G. Levy. 1985. Monocyte procoagulant activity in glomerulonephritis associated with systemic lupus erythematosus. J. Clin. Invest. 75:861868.

11. Wiggins, R. C., A. Glatfelter, and J. Brukman. 1985. Procoagulant activity in glomeruli and urine of rabbits with nephrotoxic nephritis. Lab. Invest. 53:156-165.

12. Theophilopoulos, A., P. J. McConahey, S. Izui, R. A. Eisenberg, A. B. Pereira, and W. D. Creighton. 1980 . A comparative immunologic analysis of several murine strains with autoimmune manifestations. Clin. Immun. Immunopathol. 15:258-278.

13. Steinberg, A. D., E. S. Raveche, C. A. Laskin, H. R. Smith, T. Santeno, M. L. Miller, and P. H. Plotz. 1984. Systemic lupus erythematosus. Insights from animal models. J. Clin. Invest. 100:714-727.

14. Bevilacqua, M. P., D. Amrani, M. W. Mosesson, and C. Bianco. 1981. Receptors for cold-insoluble globulin (plasma fibronectin) on human monocytes. J. Exp. Med. 153:42-60. 
15. Levin, J., P. A. Tomasulo, and R. S. Oser. 1970. Detection of endotoxin in human blood and demonstration of an inhibitor. J. Lab. Clin. Med. 75:903-911.

16. McCluskey, R. T. 1975. Lupus nephritis. In Kidney Pathology Decentennial. 1966-1975. S. C. Summers, editor. Appleton-Century Crofts, East Norwalk, CT. 435-460.

17. Mizel, S. B., J. J. Oppenheim, and D. L. Resenztreich. 1978. Characterization of lymphocyte activating factor (LAS) produced by the macrophage cell line P388D1. J. Immunol. 20:1497-1503.

18. Gillis, S., A. M. Fern, W. Ou, and K. A. Smith. 1978. P. T. cell growth factor: parameters of production and a quantitative immunoassay for activity. J. Immunol. 120:2027-2032.

19. Deutsch, H., and D. Mertz. 1970. Isolation and purification of plasminogen. Nature (Lond.). 170:1095-1096.

20. York, J. L., and B. Blomback. 1979. The sites of the lactoperoxidase catalyzed iodination of human fibrinogen. J. Biol. Chem. 254: 8786-8791.

21. Leibowitz, J. L., L. S. Fung, and G. A. Levy. 1983. A sensitive radioimmunoassay for the determination of antibodies to mouse hepatitis virus. J. Virol. Methods. 6:255-265.

22. Fishman, W. H. 1955. Beta glucuronidase. Adv. Enzymol. Relat. Areas Mol. Biol. 16:361-72.

23. Murphy, E. D., and J. B. Roths. 1978. New inbred strains. Mouse Newsletter. 58:51-53.

24. Andrews, B. S., R. A. Eisenberg, A. N. Theophilopoulos, S. Izui, C. B. Wilson, P. J. McConohey, E. Murphy, J. B. Roths, and F. J. Dixon. 1978. Spontaneous murine lupus-like syndromes. Clinical and immunopathological manifestations in several strains. J. Exp. Med. 148:11981215.

25. Schoenfeld, Y., and R. S. Schwartz. 1984. Immunologic and genetic factors in autoimmune diseases. N. Engl. J. Med. 311:10191029.

26. Edgington, T. S., H. Helin, S. A. Gregory, D. S. Fair, G. A. Levy, and B. S. Schwartz. 1985. Cellular pathways and signals for the induction biosynthesis of initiators of the coagulation protease cascade and of plasminogen activators in cells of the monocyte lineage. In The Macrophage. E. Wisse, editor. Elsevier/North Holland, Amsterdam. 681.
27. Colvin, R. B., M. W. Mossesson, and H. F. Dvorak. 1979. Delayed type hypersensitivity skin reactions in congenital afibrinogemia lack fibrin deposition and induration. J. Clin. Invest. 63:1302-1306.

28. Edgington, T. S., B. S. Schwartz, G. A. Levy, and D. S. Fair. 1982. Unidirectional T lymphocyte induction of monocyte procoagulant molecules. In Immunopathology: VIII International Symposium. F. Dixon, editor. Academic Press, Inc., New York. 25-55.

29. Schwartz, B. S., and T. S. Edgington. 1981. Immune complex induced human monocyte procoagulant activity. A rapid unidirectional pathway. J. Exp. Med. 154:892-989.

30. Edwards, R. L., and F. R. Rickles. 1980. The role of human T cells and $\mathrm{T}$ cell products for monocyte tissue factor generation. J. Immunol. 125:606-609.

31. Prydz, H., T. Lyberg, P. Deteix, and A. C. Allison. 1979. In Vitro stimulation of tissue thromboplastin (Factor III) activity in human monocytes by immune complexes and lectins. Thromb. Res. 15:465474.

32. Geczy, C. L., and K. E. Hopper. 1981. A mechanism of migration inhibition in delayed-type hypersensitivity reactions. II. Lymphokines promote procoagulant activity of macrophages in vitro. J. Immunol. 126: 1059-1065.

33. Geczy, C. L. 1984. The role of lymphokines in delayed-type hypersensitivity reactions. Springer Semin. Immunopathol. 7:321-346.

34. Striker, G. E., M. Mannik, and M. Y. Turg. 1979. Role of marrow derived monocytes and mesangial cells in removal of immune complexes from renal glomeruli. J. Exp. Med. 149:127-136.

35. Schwartz, B. S., G. A. Levy, D. A. Fair, and T. S. Edgington. 1982. Murine lymphoid procoagulant induced by bacterial lipopolysaccharide and immune complex is a monocyte prothrombinase. J. Exp. Med. 155:1464-1479.

36. Geczy, C. L., I. M. Roberts, P. Meyer, and L. C. Bernard. 1984. Susceptibility and resistance to experimental autoimmune encephalomyelitis and neuritis in the guinea pig correlate with the induction of procoagulant and anticoagulant activities. J. Immunol. 133:3026-3036.

37. Bar-Shavit, R., A. Kahn, and G. D. Wilner. 1983. Monocyte chemotoxis: stimulation by specific exosite region in thrombin. Science (Wash. DC). 220:728-731. 